\title{
Distillasie van tetrafluooretileen, heksafluoor- propileen en oktafluoorsiklobutaan by lae temperature
}

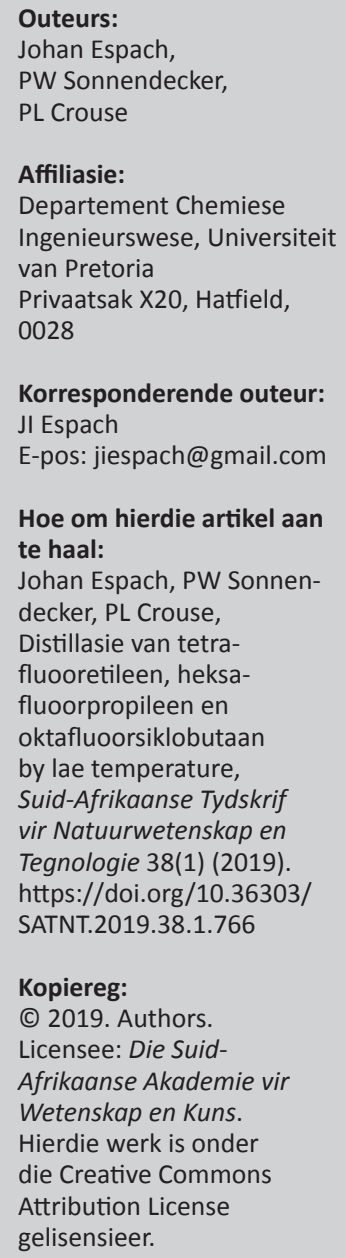

\begin{abstract}
Distillation of tetrafluoroethylene, hexafluoropropylene and octafluorocyclobutane at sub-zero temperatures: A new distillation column configuration is under investigation to be used to separate ternary mixtures of tetrafluoroethylene, hexafluoropropylene and octafluorocyclobutane. In the new configuration, an accumulating reboiler is utilised as a condenser, with energy directly supplied to the system by the incoming gaseous feed.
\end{abstract}

Politetrafluooretileen (PTFE) is 'n gewilde polimeer wat in verskeie industrieë gebruik word weens die hitte- en chemiese bestendigheid en lae wrywingskoëffisiënt van die materiaal. PTFE het egter ' $n$ baie hoë viskositeit in die gesmelte toestand en kan dus nie met behulp van konvensionele metodes herwin word nie. Gevolglik moet PTFE deur middel van pirolise na sy monomeer afgebreek word om die herwinningsiklus voort te sit.

Die ontbindingsreaksie van PTFE produseer hoofsaaklik tetrafluooretileen (TFE) by lae druk ( $\leq 5 \mathrm{kPa}$ ) en hoë temperatuur (tussen 500 en $760{ }^{\circ} \mathrm{C}$ ). ' $\mathrm{n}$ Toename in beide druk en temperatuur veroorsaak dat TFE sekondêre reaksies ondergaan om heksafluoorpropileen (HFP) en oktafluoorsiklobutaan (OFSB) te produseer. Buiten TFE is beide HFP en OFSB hoëwaardeprodukte en is dit dus van belang om dié driekomponent-mengsel te skei.

Die gekose skeidingsmetode is deur middel van distillasie onder koue prosestoestande, aangesien TFE, HFP en OFSB se kookpunte by 1 bar as onderskeidelik $-76.3,-28$ en $6{ }^{\circ} \mathrm{C}$ voorkom. Dit is egter moeilik om kontinue kleinskaalse skeiding te behaal aangesien pompe wat sulke lae temperature kan hanteer, moeilik bekombaar is. Daarbenewens vries OFSB by $-40.1{ }^{\circ} \mathrm{C}$, wat dit nie moontlik maak om die mengsel in die vloeistoffase, of selfs as ' $n$ tweefasemengsel naby dié temperatuur, te voer nie.

'n Nuwe distillasiekolomopset word dus ondersoek om die bogenoemde probleme te oorkom. Die nuwe kolomopstelling verskil van konvensionele konfigurasies hoofsaaklik omdat die opkoker as 'n kondensator aangewend word. Die bodemproduk vermis ook 'n uitlaat sodat dit binne-in die kondensator kan opgaar. Die doel hiermee is om so min as moontlik OFSB in die kolom op te stuur om sodoende 'n TFE-HFP binêre sisteem te skep. Dié doel kan verder verwesenlik word deur die bodemproduk se kondensator onder OFSB se vriespunt te bedryf.

Warmte word aan die sisteem oorgedra deur die afvoer van die gasfase aan die onderkant van die kolom in te stuur en dus skeidingsdryfkrag te skep. Beide grafiese en rekenaarmodellering van die sisteem (deur middel van die McCabe-Thiele grafieke en die Aspenmodelleringsprogram) voorspel dat die nuwe kolomopstelling ' $n$ TFE van hoë suiwerheid sal lewer, ten koste van 'n totale opbrengs wat laer is in vergelyking met konvensionele distillasiemetodes. Die modelleringtoestande benader egter die kolomopstelling deur nie in ag te neem dat die bodemproduk se uitlaat vermis is nie. Positiewe eksperimentele resultate van die kolomopstelling sal dus oorgaan na die ontwikkeling van 'n beter model vir die kolom.

Nadat TFE uit die sisteem verwyder is, kan die HFP-OFSB binêre sisteem geskei word deur die bodemkondensator weer as 'n opkoker aan te wend en die mengsel deur middel van lotdistillasie te skei.

Nota: 'n Seleksie van referaatopsommings: Studentesimposium in die Natuurwetenskappe, 25-26 Oktober 2018, SA Akademiegebou, Pretoria, Suid-Afrika. Gasredakteurs: Prof Rudi Pretorius (Departement Geografie, Universiteit van Suid-Afrika); Prof Chris Swanepoel (Departement Besluitkunde, Universiteit van Suid-Afrika); Me Andrea Lombard (Departement Geografie, Universiteit van Suid-Afrika) 